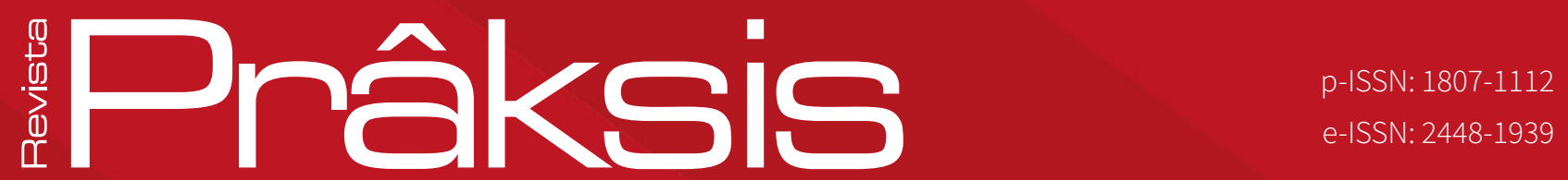

Aprovado em: 20 de junho de 2018

Sistema de Avaliação: Double Blind Review

RPR |a. 15 |n. 2 | p. 06-22 | jul./dez. 2018

DOI: https://doi.org/10.25112/rpr.v2i0.1636

\title{
UMA CARTOGRAFIA DO AFETO: A PRESENÇA da AusêNCIA Em DE MIM Já NEM SE LEMBRA
}

\section{A CARTOGRAPHY OF AFFECTION:}

THE PRESENCE OF ABSENCE IN DE MIM JÁ NEM SE LEMBRA

\section{Andressa Macena Maia}

Mestranda em Literatura brasileira contemporânea e estudos culturais (Universidade do Novo México/Estados Unidos).

E-mail: amaia@unm.edu.

\section{Leila Maria Lehnen}

Doutora em Espanhol e Português (Vanderbilt University/Estados Unidos).

E-mail: amaia@unm.edu. 


\section{RESUMO}

Esse ensaio analisa a obra De mim já nem se lembra, de Luiz Ruffato (2016), através de um mapeamento do sujeito social e de que forma sua narrativa atravessa os lugares por onde passa. Através da troca de cartas com a mãe, que permanece em Cataguazes, José Célio constrói um espaço único de pertencimento e afetividade através do relato de sua trajetória individual e solitária em São Paulo, cartografada por lugares diferentes e marcada pela ausência. Por isso, esse romance epistolar pode ser visto como uma estratégia de resistência do sujeito ao apagamento do espaço da memória, do afeto e das relações significativas, como consequência do processo modernizador autoritário imposto pela ditadura militar no Brasil à época.

Palavras-chave: Migração. Afeto. Modernização. Ditadura militar.

\section{ABSTRACT}

This essay analyzes De mim já nem se lembra from Luiz Ruffato (2016), through a cartography of José Célio, and how his narrative traverses the places he goes through. Through the exchange of letters with his mother, who remains in Cataguases, José Célio's home town, he aims to build a unique space of belonging and affectivity through the account of his individual and solitary trajectory in São Paulo, mapped by different places and marked mainly by absence. For this reason, this epistolary novel can be considered as a strategy of resistance of the agent to the erasure of the space of memory, affection and significant relationships, as a consequence of the authoritarian modernizing process established by the dictatorship in Brazil.

Keywords: Migration. Affection. Modernization. Dictatorship. 


\section{INTRODUÇÃO}

Na década de 70, o Brasil passou por um intenso fluxo migratório que alimentou os grandes centros metropolitanos do Sudeste. Essas migrações foram uma das consequências do discurso modernizador autoritário1, ideologia proposta pela ditatura militar (1964-1985). Famílias, espaços sociais e afetivos foram sacrificados em busca de melhores condições de vida.

AcidadedeSão Pauloeraoprincipal destinodosmigrantes, dadaa efervescênciadoseu desenvolvimento urbano, econômico e industrial. No princípio da década de 70, intensificou-se a necessidade de mãode-obra para alimentar os grandes parques industriais que estavam sendo construídos na região hoje conhecida como ABC paulista². Minas Gerais, estado que faz fronteira com São Paulo, contribuiu com muitos de seus habitantes, que embarcaram nessa viagem em busca de melhores condições de vida.

A industrialização - e concomitante demanda por mão de obra - deu-se em grande parte graças ao "milagre econômico brasileiro" (1969-1973)3. Durante esse período, as políticas econômicas que a ditadura implementou, tais como a correção da inflação e a fundação do Banco Central, trouxeram aparentes melhorias econômicas para o país - ao menos por um período limitado. A economia cresceu, mas este crescimento não foi visto ou vivido por todas as classes sociais. Há debates sobre o impacto dessas melhorias econômicas, já que uma pequena parcela da população foi favorecida: a classe média. O crescimento expressivo do PIB (Produto Interno Bruto), de 9,8\% a.a. em 1968 para 14\% a.a. em 19734, trouxe como consequência não só a criação de empregos e a melhoria econômica para a classe média, mas também gerou o aumento da inflação, que cresceu de 19,46\% a.a. em 1968 para 34,55\% em 19745. A inflação, por sua vez, afetou a qualidade de vida da população brasileira, principalmente das classes populares que viram seus salários serem comprimidos.

\footnotetext{
${ }^{1} O$ termo é empregado ao longo do ensaio como referência ao modelo de modernização conservadora e ditatorial, impulsionada pelo Estado de exceção, pela articulação de capital nacional e estrangeiro.

${ }^{2}$ ABC paulista é considerado o primeiro centro automobilístico do Brasil, e compreende algumas cidades da região metropolitana do estado de São Paulo, tem esse nome como uma abreviação das principais cidades que o compõe: Santo André (A), São Bernardo (B) e São Caetano do Sul (C). O parque industrial foi um reflexo do discurso modernizador autoritário, consequência da abertura do mercado nacional para a entrada de capital estrangeiro e companhias internacionais.

${ }^{3} \mathrm{O}$ "milagre" econômico foi a condução firme da economia brasileira pelo Estado de exceção que se beneficiou de uma conjuntura econômica internacional favorável, incluindo a entrada de capital estrangeiro no país.

4 Dados retirados de: VELOSO, Fernando A.; VILLELA, André; GIAMBIAGI, Fabio. Determinantes do 'milagre' econômico brasileiro (1968-1973): uma análise empírica. Revista Brasileira de Economia, v. 62, n. 2, p. 221-246, 2008.

${ }^{5}$ Dados retirados do artigo supracitado. 0 aumento dos juros afetou significativamente as camadas menos favorecidas e os trabalhadores assalariados foram definitivamente afetados, tendo seu poder de compra reduzido.
} 
Tendo em vista esta conjetura histórico-social, esse ensaio tem como objetivo traçar a cartografia da formação do sujeito social analisando-se o impacto da migração na formação da subjetividade e da memória na obra De mim já nem se lembra (2016), de Luiz Ruffato. Através do recurso do gênero epistolar, o protagonista-narrado, José Célio, relata à sua mãe sua trajetória social e afetiva em São Paulo, cartografada por lugares diferentes e marcada pela ausência. Este relato é ao mesmo tempo uma relação da condição do sujeito vis-à-vis sua condição de migrante e um retrato do Brasil na década de 70. O romance começa em 1971 e termina em 1978, às vésperas das greves do ABC paulista e que enfraqueceram o poder da ditadura.

Esse ensaio busca apontar evidências do estranhamento e do não pertencimento do sujeito migrante ao espaço físico que habita em De mim já nem se lembra. O relato da solidão do sujeito migrante, do seu desenraizamento, sugere uma crítica do projeto modernizador que a ditadura militar empreendeu. Apesar de não estar relatada através das torturas e das mortes, a ditadura militar está presente ao longo do romance de Ruffato. A década de 70 não foi somente o período do "milagre econômico", foi também a época em que Brasil passou pelos "anos de chumbo"6, o ápice da censura, violência e violação dos direitos humanos durante o regime de exceção. De mim já nem se lembra toca indiretamente nestes pontos, focando-se mais no esgarçamento dos laços sociais e afetivos decorrentes do projeto econômico do governo militar. Ou seja, o romance de Ruffato nos mostra uma outra manifestação da violência social imposta pela ditadura aos cidadãos brasileiros. Trata-se de uma violência menos explícita, mas nem por isso menos perniciosa.

De mim já nem se lembra apresenta vozes narrativas ambíguas. O romance é construído por fragmentos de memórias de diversos personagens, em diferentes momentos históricos e políticos do Brasil. Além do narrador-autor, que assume ser o próprio Luiz Ruffato, temos as missivas de José Célio à mãe. A existência das cartas em si é ambivalente. Como afirma Ruffato em entrevista a Guilherme Freitas:

Tudo que está no livro é verdade, mas tudo que está no livro é ficção. Meu irmão, minha mãe e outros parentes são citados com os nomes reais, há um personagem secundário com meu nome, as questões nas cartas do irmão são reais, o relato sobre a morte da mãe é próximo do que aconteceu comigo. Mas quem disse que as cartas existem? Não garanto. Toda literatura, de uma forma ou de outra, é autoficção, mas não gosto daquela que se "vende" como autoficção.?

\footnotetext{
${ }^{6}$ A expressão "anos de chumbo" refere-se a um período específico do regime de exceção no Brasil, de 1968 a 1973 . Foi a fase mais repressora do regime, com o maior número de prisões, torturas, mortes e desaparecimentos. Começa justamente com a proclamação do Ato Institucional número 5.
}

7 Disponível em: <https://oglobo.globo.com/cultura/livros/cada-romance-uma-tentativa-de-reconstruir-historia-diz-ruffato-1 8960961>. Acesso em: 23 mai. 2018. 
A indeterminação narrativa e a fluidez mnemónica que ela implica permitem que o escritor utilize a literatura como espaço de expressão de outras vozes narrativas, vozes muitas vezes ofuscadas na literatura brasileira, reconstruindo a memória individual e coletiva nacional. Como afirma Ruffato na entrevista sobrecitada:

Cada romance meu é uma tentativa de reconstruir a História do país a partir de um ponto de vista pouco presente na literatura brasileira, o do trabalhador urbano. Em "Inferno provisório", eu já tinha abordado o período da ditadura, mas numa cidade do interior. Em De mim já nem se lembra quis falar da ditadura de uma forma mais direta, sem ser explícita. A ditadura é vista por um trabalhador que a princípio não entende muito bem o que está acontecendo e vai compreendendo aos poucos, por conta própria. ${ }^{8}$

Ao publicar as cartas supostamente escritas por seu irmão, o autor tem como objetivo costurar os retalhos de uma colcha, conectando e entrelaçando os fragmentos da memória ainda sobrevivente do irmão, ao mesmo tempo que pontua estes fragmentos com detalhes históricos que localizam a voz do irmão dentro de um contexto social específico. Ao resgatar a memória do irmão e sua voz nas cartas recuperadas, Ruffato, de certa forma, também resgata não somente a sua memória individual, mas também a memória da família, da comunidade e, consequentemente, promove o resgate da memória coletiva. A narrativa do romance de certa forma contradiz, se contrapõe ao esquecimento do indivíduo, de quem "já nem se lembra", mas também de facetas da história brasileira, incluindo a violência social que a ideologia da ditadura militar impôs ao país.

De mim já nem se lembra tira José Célio do passado trazendo sua voz para o presente, transformando uma personagem anônima em literária. Através da publicação das cartas supostamente esquecidas e desaparecidas no fundo de uma gaveta, o protagonista em De mim já nem se lembra pode sobreviver, sair do anonimato, ter agência e representar milhares de brasileiros anônimos e esquecidos que viveram o mesmo drama da quebra das relações familiares como consequência da migração na década de 70 .

As políticas econômicas impostas durante o regime de exceção e suas consequências para a classe trabalhadora são o ponto de partida da obra, como uma tentativa de evidenciar o apagamento do sujeito migrante no lugar para onde se desloca. Com a partida, o migrante rompe a rede de afetividade constituída no lugar de origem. O sujeito migrante encontra-se em um estado anômico (Durkheim, 1897) pois localiza-se em uma espécie de vácuo social.

8 Disponivel em: <https://oglobo.globo.com/cultura/livros/cada-romance-uma-tentativa-de-reconstruir-historia-diz-ruffato-18960961>. Acesso em: 23 mai. 2018. 
Em De mim já nem se lembra, a manutenção dos laços de afetividade mostra-se desafiadora por causa da distância geográfica, e também social, que se aprofunda com o passar do tempo. As cartas intercambiadas entre José Célio e sua mãe são uma tentativa de diminuir esta distância. No entanto, paradoxalmente, cada carta lida ao longo do romance confirma o afastamento do lugar de afeto e a aproximação com o lugar do trabalho e o isolamento social do protagonista-narrador.

O espaço é um marcador narrativo importante da obra de Ruffato e será analisado nesse trabalho na visão de diferentes autores. Michel de Certeau (1987) trará a luz interpretativa com seu binário lugar e espaço. O ensaio também empregará as teorias de Marc Augé (1995) para abordar como a obra representa os conceitos de lugar e não lugar. Finalmente, a ideia da modernidade líquida de Zygmunt Bauman (2000) vai ajudar na contextualização do processo de modernização que o Brasil estava sofrendo à época. Busca-se situar de que forma o(s) narrador(es) constroem essa relação de pertencimento ou não com as comunidades em que se encontram geograficamente e socialmente, sob a luz da teoria supracitada. 0 espaço ressalta a presença da ausência (física, emocional e social) que por sua vez faz referência à dor da saudade do membro da família "perdido" para a modernização e o aparente desenvolvimento econômico do Brasil na década de 70. 0 espaço físico, em particular, a cidade de São Paulo, representa a fragilização das relações sociais e afetivas do sujeito migrante. Trata-se de um não espaço, na definição de Augé. Dessa forma, as cartas de José Célio podem ser analisadas como uma tentativa de construção de um espaço de resistência ao apagamento do papel social, das relações afetivas e da memória do sujeito migrante dentro do processo de modernização imposto pela ditadura militar.

\section{A PRESENÇA DA AUSÊNCIA}

Em De mim já nem se lembra, Luiz Ruffato traz à tona uma perspectiva da história do Brasil até então pouco explorada na literatura brasileira contemporânea. Em sua obra, apresenta o outro lado do processo de modernização que o Brasil estava passando na década de 70: o lado humano, afetivo e social das classes menos favorecidas. 0 autor discute o universo destas classes populares, principalmente dos trabalhadores operários, através do registro da rotina de um sujeito produtor e consumidor da modernidade, carente de afeto e deslocado fisicamente e socialmente do núcleo familiar.

Apesar do autor mencionar o nome dos seus familiares e ter escrito esse livro como "forma de reparar seus mortos, que pesam no lado esquerdo" (p. 20), não há como precisar se é uma história autobiográfica ou não. Trata-se de literatura e o autor brinca com essa voz narrativa que navega entre realidade e ficção, deixando a cargo do leitor decidir se a(s) história(s) relatada(s) são parte do universo ficcional ou verídico.

Assim acontece com as cartas que dão corpo à obra. Foram supostamente escritas na década de 70 , enquanto José Célio morava em São Paulo, e descreviam sua trajetória, seus êxitos e dissabores da sua 
vida na cidade grande. Depois de sua morte em um trágico acidente de carro, as cartas foram silenciadas por vinte anos, existindo somente na trajetória narrativa ${ }^{9}$ da mãe, que lutava para manter viva a memória do filho morto. A necessidade de resgate da memória familiar só veio à tona com a morte da mãe e a necessidade de "limpar" a materialidade das suas lembranças, roupas e objetos pessoais. A voz autoral conta que somente decide publicá-las muitos anos depois dele mesmo passar por várias mudanças na trajetória da sua narrativa, reflexo de mudanças geográficas e psicológicas em sua própria vida.

Através do gênero epistolar, Ruffato aproxima o/a leitor/a da obra, tornando-o/a parte essencial da materialização das cartas e, pelo tanto, da recuperação da memória do irmão e de parte da história do Brasil. Embora as cartas tenham sido enviadas à mãe, o leitor é o destinatário final das correspondências enviadas por José Célio. Assim, Ruffato busca aproximar o leitor da sua obra, transformando em literatura a "quase-oralidade" (p. 20) do registro das memórias da personagem.

Devido ao caráter metaficcional da obra, não é possível precisar se o Luiz Ruffato narrador também é o escritor. A obra é composta por 3 partes; em "explicações necessárias" (p. 09), como o próprio título já atribui, o Luiz Ruffato narrador explica o contexto em que as cartas foram encontradas. Há também a carta escrita por ele ao irmão, José Célio, em "apêndice" (p. 131), como uma forma de resposta tardia às cartas encontradas e publicadas em "as cartas" (p. 23), escritas por José Célio a sua mãe, em um intervalo de 7 anos, enquanto morava em São Paulo.

Outros elementos narrativos do romance, como gradientes sensoriais, também precisam ser considerados no presente ensaio. Esses gradientes funcionam como importantes fios condutores para construção e manutenção da memória ao longo da narrativa.

Um dos gradientes sensoriais mais importantes da obra é a percepção espacial de José Célio. Na sua chegada e durante toda sua estadia, o narrador-protagonista se impressiona com a magnitude da cidade, que contrasta com a pequenez de Cataguases, cidade de origem de José Célio (e do próprio Ruffato). 0 assombro do narrador-protagonista fica evidente quando este tenta descrever a dimensão da metrópole à mãe em uma das cartas que envia a esta: "diz o Nilson que isso não é nada, que não vi nem um décimo da cidade" (p. 27). Aqui a voz narrativa se posiciona frente ao tamanho desmesurado da urbe paulista. Sua visão literalmente limitada evoca seu posicionamento social marginalizado dentro da metrópole.

De mim já nem se lembra é composta por coordenadas espaciais que auxiliam na distinção entre o espaço físico de Cataguases, sua cidade natal, e São Paulo, lugar para onde migra. O narrador relata com

\footnotetext{
${ }^{9}$ A trajetória narrativa, segundo Michel de Certeau (1987), diz respeito às práticas sociais do sujeito, suas experiências individuais de construção da sua narrativa pessoal.
} 
descrições detalhadas a dificuldade do deslocamento na cidade grande, devido à magnitude da cidade e as longas distâncias que precisa percorrer para mover-se de um ponto a outro como em "a gente pegou um ônibus, andou pra chuchu, pegou outro e só aí a gente chegou aqui no Ipiranga" (p. 27), e "[...] tenho que sair de casa as 5 da manhã, pego um ônibus até o Vale do Inhangabaú e outro pra Diadema e só chego em casa lá pelas 7 horas" (p. 31). Essa passagem reflete a realidade de milhares de brasileiros que precisam viajar por longas horas para chegar a seus trabalhos nos centros urbanos das grandes cidades.

O paladar, outro gradiente marcante na obra, constrói a memória sinestésica, marcada pelo espaço do afeto, representado pela comida da mãe, da qual José Célio tanto sente falta. A comida materna serve como ponto de comparação, como âncora e fonte de nostalgia: "a comida é boa, [...] claro, não é nem de longe parecida com a comida da senhora e disso sinto falta, tempero igual ao da senhora não existe" (p. 31). O tempero materno simboliza um outro espaço, uma outra vivência que desaparece nas relações anônimas, contratuais da cidade grande. As diferentes lembranças auxiliam na construção dessa rede de memória afetiva que a personagem tem a necessidade de criar, como forma de compensar a ausência do afeto da família e da sociabilidade deixada atrás em Cataguases.

Pode-se, ainda, apontar o contraste entre a marcação do tempo cronológico e do tempo psicológico do(s) narrador(es) ao longo da obra. Em "como o tempo passa rápido quando estamos fora de casa" (p. 33) e "nunca tinha viajado tanto tempo dentro de um ônibus" (p. 25), há uma percepção diferente do tempo narrativo para o tempo vivido, devido à distância do núcleo familiar e à saudade existente. $A$ conceitualização de tempo varia com a proximidade ou distanciamento (físico e emocional) da família, além da saudade que o protagonista sente. 0 tempo encolhe-se ou estica-se conforme as experiências de José Célio.

Ao anular-se das relações afetivas, o protagonista permite um espaço maior em sua vida para as relações de trabalho, produção e consumo. Assim, as relações afetivas são reduzidas, mas não eliminadas, pelas relações de trabalho. Pode-se ler a ênfase nas relações de trabalho, no espaço da contratualidade que o romance de Ruffato representa como uma crítica ao projeto de modernização imposto pela ditadura. Ou seja, este projeto concentra-se apenas no desenvolvimento econômico, não na melhoria social. 0 sujeito transforma-se em produtor, obviando-se seu papel como cidadão, como indivíduo.

Aqui, faz-se importante recorrer às definições de espaço e lugar de Michel deCerteau (1984), pertinentes a esse ensaio. Lugar é definido como "a ordem (de qualquer tipo) de acordo com quais elementos são distribuídos em relação de coexistência" ${ }^{10}$ (p. 117). Já o espaço é o "lugar praticado" (p. 117). Dito de outra

\footnotetext{
${ }^{10}$ Essa e todas as citações do ensaio foram traduzidas pela autora.
} 
forma, o espaço representa as práticas narrativas do sujeito, a história pessoal, individual e intrasferível de suas vivências e experiências num determinado lugar. Um mesmo sujeito pode escrever narrativas diferentes em lugares diferentes; enquanto o lugar é a localização dessas práticas, podendo ser habitado por narrativas diferentes de múltiplos sujeitos, num processo de justaposição e coexistência. Um mesmo lugar pode ser habitado por diferentes práticas narrativas, já que cada uma reflete a experiência subjetiva e individual de cada sujeito social. Portanto, o lugar só existe enquanto espaço se houver uma narrativa construída através da trajetória experienciada pelo sujeito social.

Na obra de Ruffato, a troca de cartas entre José Célio e sua mãe representa a materialização dessa jornada narrativa do protagonista, através da construção de um espaço de pertencimento e agência social, representando, assim, o espaço das práticas sociais de Michel de Certeau. Como consequência do deslocamento de um lugar físico para outro, a narrativa construída e vivida no lugar em que se encontra é diferente. Através das cartas, José Célio consegue exercer o papel de sujeito agente de seu próprio destino, relatando a vida da cidade grande e sua tentativa frustrada de construir seu espaço narrativo e adaptar-se ao novo lugar. As cartas, como "lugar praticado" (p. 117), materializam as realizações, frustrações e, principalmente, a necessidade de manutenção de um vínculo de afetividade não existente no lugar em que se encontra, São Paulo. Isso fica evidente em diversas passagens do romance como em "nunca pensei que a gente sentia tanta falta das pessoas queridas" (p. 39) e "por mais que a gente queira se adaptar, lugar da gente é um só, não tem jeito" (p. 48). O processo de adaptação à cidade grande e suas possíveis práticas sociais se enfraquecem, à medida que o protagonista percebe que o estabelecimento de possíveis relações de afeto no lugar de destino não substitui o afeto do lugar de origem. Ou seja, São Paulo é um lugar anômico, onde o sujeito vive, principalmente, as relações de trabalho, sacrificando a dimensão afetiva e até mesmo social da sua existência.

Outro teórico relevante para esse ensaio é Marc Augé (1995) e sua definição de lugar e não lugar. Augé determina o "lugar como feito pela palavra, através da troca alusiva de alguns códigos de acesso entre os falantes que convivem em um território particular de cumplicidade, [...] pode ser definido como relacional, histórico e relacionado à identidade, [...]" (p. 63). Em outras palavras, é no lugar que o sujeito se reconhece, forma sua identidade social e identifica os membros da sua comunidade, através das manifestações culturais particulares e dos códigos internos de convivência e comunicação. Portanto, todo o processo de escritura das cartas no texto de Ruffato, desde a motivação para a escrita, o movimento de materialização das memórias e sentimentos, a troca de confidências em palavras escritas e registradas no papel podem ser relacionadas ao lugar de Augé. Através das missivas, o protagonista constrói seu lugar de expressão e reconhecimento, lugares esses que não existem no espaço físico em que habita. Esses 
lugares são construídos como uma tentativa de resistência ao processo desumanizador das relações de trabalho, que transforma os trabalhadores em engrenagens de uma máquina, representada pelo estado de exceção. 0 seguinte trecho do romance evidencia a construção desse lugar de pertencimento e afeto, através da intimidade estabelecida entre mãe e filho: "desculpa o desabafo, mas não tenho mais ninguém com quem conversar. Não tenho amigos de verdade aqui, a única coisa que faço é trabalhar, trabalhar, trabalhar" (p. 72). Por mais que o protagonista lute contra o apagamento imposto pela modernização, a construção desse espaço afetivo dentro da escrita é o único lugar onde logra expressar suas frustrações e anseios.

Para contrapor à definição de lugar, Augé diz que "a supermodernidade ${ }^{11}$ produz não lugares [...], não integra os lugares antes experienciados, ao contrário, são listados, classificados e promovidos para um status de 'lugares da memória', e atribuídos a uma posição específica e circunscrita" (p. 63). 0 não lugar é o oposto de lugar, definido como o espaço onde "(..) relações são renovadas e assumidas" (p. 64). Em sua obra, Augé contrapõe sua teoria com a de Michel de Certeau para espaço e lugar, apresentada anteriormente, para estabelecer uma comparação com a sua própria definição de lugar e não lugar. "A distinção entre lugares e não lugares, deriva da oposição entre lugar e espaço" (p. 64). Dito de outra forma, o não lugar da supermodernidade pode ser considerado como um lugar de passagem, um entrelugar de relações sociais superficiais ou inexistentes, que conecta um lugar de origem a um lugar de destino. Na obra de Ruffato, José Célio passa por diferentes rodoviárias no seu deslocamento entre Cataguases, São Paulo e outras cidades por onde circula, pega ônibus com pessoas estranhas que não se comunicam entre si e, quando o fazem, é superficialmente. Fica evidente o distanciamento da jornada narrativa do protagonista e sua tentativa de fazer-se presente em lugares de ausência. Além disso, como mencionado anteriormente, a cidade de São Paulo é, em si, um não lugar para José Célio. Ele está constantemente de passagem na metrópole, deslocando-se fisicamente, mas também se sentindo deslocado psicologicamente. Como indicado, as cartas que ele envia à mãe são um lugar onde ele pode se constituir enquanto sujeito social e onde ele pode encontrar traços da afetividade deixada para trás.

De mim já nem se lembra é composta por lugares, onde os narradores constroem seus espaços narrativos, e de não lugares, espaços de não protagonismo do sujeito. São Paulo pode ser definida como o não lugar mais importante da obra. As tentativas de vivenciar a comunidade, criar vínculos de afetividade e construir relações que preencherão o espaço da memória não funcionam nesta urbe esmagadoramente

\footnotetext{
${ }^{11}$ Augé define os lugares da supermodernidade como espaços entre-lugares, preenchidos por relações contratuais, e deslocamentos impessoais. Como o recorte temporário do ensaio abarca o Brasil dos anos 70, a definição do teórico de não lugar é empregada, não associada à supermodernidade, e sim ao início da modernização do país à época.
} 
grande, anônima. José Célio tenta buscar por esse espaço de afeto em São Paulo, mas apenas consegue estabelecer relações de trabalho. Dessa forma, as cartas representam o único lugar de expressão de afeto de José Célio. A solidão somente é interrompida nas poucas vezes que regressa a Cataguases para visitar a família. Nessas visitas, o narrador tenta - nem sempre exitosamente - reatar laços, formular novas memórias afetivas, recriar, enfim, a sociabilidade afetiva que a cidade grande anula. Através das cartas, José Célio também estabelece um diálogo entre presente e passado, acessando sua memória como forma de reviver e revisitar as relações de afeto do passado e sobreviver à realidade presentefuturo da metrópole.

Desde a primeira carta trocada com a mãe, José Célio expressa seu sofrimento e tristeza pela partida do seio familiar. "Me deu um nó na garganta, medo de nunca mais ver a senhora, o pai, o Luizinho, meus amigos, nossa casa. Mas eu sei que é preciso lutar pra melhorar de vida." (p. 26). José Célio mostra-se consciente da quebra das relações sociais que se dá devido à migração. No entanto, sua fala também revela a internalização do discurso propagado pela ditadura, a ideia do trabalho como forma de obter um melhor futuro, da melhoria econômica possível através do processo migratório. 0 isolamento de José Célio aponta às consequências da modernização conservadora proposta pela ditadura militar ao nível pessoal.

Na passagem "a firma vai me comprar as férias. Assim mando dinheiro para a senhora pagar essas contas e comprar material escolar [...]" (p. 46), o narrador deixa explícita a necessidade de manter-se afastado do convívio familiar para poder ajudar a família financeiramente. 0 tempo do trabalho passa a ser mais valioso que o tempo do afeto. As relações na modernidade se tornam fluídas, efêmeras, próximas ao total apagamento. 0 projeto econômico da ditadura militar segue injetando capital estrangeiro na economia do Brasil, exigindo o aumento da produção dos bens de consumo, buscando mercado consumidor.

Embora José Célio tenha dificuldade em adaptar-se a São Paulo, ele reconhece a necessidade de estar lá:

Foi muito difícil entrar naquele ônibus e voltar pra São Paulo. Lá em Leopoldina, esperando o ônibus que vinha de Alegre, veja só o nome da cidade, e eu numa tristeza que dói, [...] com uma vontade danada de pegar minha mala e voltar pra casa, abraçar a senhora e o pai, a Lúcia, o Luizinho, e falar, não, não quero voltar não, mas eu sei que não posso fazer isso, que a gente não escolhe os caminhos e que meu dever é tentar ganhar a vida em São Paulo. Mas não é fácil (p. 39).

$O$ protagonista não esconde a dificuldade emocional em superar a tristeza e a saudade da família ao longo do processo de deslocamento. A memória e o afeto compõem o fio que o permite se conectar ao seio familiar - ou ao menos tentar - buscando combater a realidade de anulação social, auxiliando-o a não desistir de seus ideais, que também são os da sua família. A ironia fica por conta do nome da cidade, Alegre, de onde vinha o ônibus que conduziria um José Célio, triste, ao tão almejado e sofrido desejo 
de ter uma vida com melhores condições financeiras para o protagonista e sua família. A ironia é uma fissura no tecido narrativo, um momento de estranhamento que levam à reflexão sobre o conflito entre o discurso da ascensão social e a realidade do estranhamento afetivo e social.

O apagamento progressivo das relações de afetividade deixadas em Cataguases pela substituição das relações de trabalho é representado nas saudações das cartas. Se no começo a afetividade transparece na escritura, como nas saudações "Querida mãe, querido pai" (p. 25), à medida que o tempo transcorre, porém, José Célio muda seu tom, passando a usar somente "mãe" (p. 67), até o final da obra, dessa página em diante ${ }^{12}$. Essa mudança progressiva pode ser associada à necessidade de maior dedicação às relações de trabalho do que às relações de afeto. As cartas, o único espaço de agência social e afetiva do protagonista, acabam também sendo afetadas pelo isolamento social e emocional que o processo migratório efetua em José Célio.

Através de uma relação ambígua e desequilibrada com a modernização, José Célio se distancia fisicamente, emocionalmente e socialmente dos entes queridos, enquanto supostamente luta por uma vida "melhor" para ele mesmo e para sua família. Essa ambiguidade se reflete nas cartas, corroborando a hipótese desse ensaio, o esvaziamento do papel social e afetivo do sujeito migrante como consequência do discurso modernizador conservador imposto pelo estado de exceção.

Para José Célio e para milhares de brasileiros que migraram em busca de melhores condições de vida, a consequência foi a perda do papel de sujeito social, para produtor da modernidade. Ou seja, as classes populares eram responsáveis pela produção dos bens de consumo, os quais eram comercializados em abundância no Brasil à época. Apesar de serem fundamentais nesse processo de desenvolvimento econômico do Brasil, aos migrantes restava apenas o papel de produtores desses bens, e não necessariamente de consumidores. A marginalização social e econômica no lugar de destino é refletida em De mim já nem se lembra através do isolamento do protagonista-narrador, assim como do próprio título da obra que referencia justamente o apagamento do sujeito migratório. Esse apagamento do protagonista-narrador enquanto sujeito social no não lugar da modernidade fica nítido na passagem "Eu tento me adaptar a tudo, ao emprego, à cidade, às pessoas, mas sinceramente, lá no fundo, continuo um pé-rapado, um zé-ninguém [...]" (p. 72). As palavras de José Célio evidenciam como a visibilidade social está atrelada ao status social do indivíduo ("pé rapado", "zé ninguém").

\footnotetext{
12 É interessante observar a mudança progressiva nas saudações ao longo da obra. Se refere a "querida mãe, querido pai" nas páginas 25, 28, 30, 33, 36. A saudação muda para "mãe, pai" (39), e desse ponto em diante, passa a dirigir-se somente a mãe, como "mãe, querida" (43), "minha querida mãe" (45), "querida mãe" nas páginas 57, 59, 65 algumas vezes mais, intercalando com "mãe" nas páginas 47, 49, 51, 53, 55.
} 
A migração como um caminho para a ascensão social e melhora de vida revela-se como uma ilusão criada pelo "milagre econômico" que nunca existiu para a classe social de José Célio. Como afirma Paulo Kliass, ao analisar a política econômica da ditadura:

A política econômica (da ditadura) encerrava, portanto, os elementos de modernização e de atraso. Para o processo de produção e ampliação dos ganhos das empresas, as políticas públicas se encarregavam de oferecer o que de mais atual e eficiente existisse no estado das artes do capitalismo internacional. Já para os trabalhadores e para a maioria da população brasileira, o quadro era de aprofundamento da miséria e da desigualdade social e econômica. Uma frase atribuída ao General Presidente Médici, durante a época do chamado milagre, repete bem essa aparente contradição: "a economia vai bem, mas o povo vai mal".13

A ideia de que a população do Brasil como um todo seria beneficiada pelo modelo econômico imposto pela ditadura revela-se falaciosa, já que apenas as classes mais favorecidas puderam usufruir dessa melhoria. 0 "milagre" motivou o deslocamento de milhares de brasileiros para os grandes centros urbanos, intensificando a entrada de mão-de-obra barata nas grandes capitais, abastecendo as fábricas de bens de consumo não duráveis, com trabalhadores dispostos a aceitar a ausência do convívio familiar em troca de uma vida supostamente melhor, para a família que fica e para o migrante que vai. 0 protagonista tenta manter-se presente através do suporte financeiro que dá à família, além dos pequenos mimos que os envia, como relógios, jóias e dinheiro para comemorar festas de aniversário.

Quando o protagonista pergunta à mãe: "a senhora já pensou no presentinho? E o pai, o que será que ele vai querer ganhar? Não fala para Lúcia não mas vou enviar um cordãozinho de ouro para ela no aniversário dela" (p. 34), pode-se interpretar essa relação de consumo como uma substituição às relações de afeto, uma recompensa material, como uma tentativa de equilibrar a ausência. Evidencia, portanto, a substituição das relações de afeto esvaziadas pelas relações de consumo, consequências da modernidade líquida, presente no discurso modernizador autoritário proferido pelo estado de exceção. Já que José Célio está afastado fisicamente do seio familiar, tenta manter-se presente através do envio de pequenas lembranças materiais à família. Dessa forma, pode manter-se presente, além de permitir que sua família tenha acesso à bens de consumo aos quais provavelmente não teriam acesso se ele não estivesse trabalhando fora de sua cidade natal. Para poder acessar esses bens de consumo que eram símbolos da classe média nos anos 70 (televisão, máquina de lavar) que antes não podia ter

\footnotetext{
${ }^{13}$ Disponivel em: <https://www.cartamaior.com.br/?/Coluna/O-golpe-de-64-e-a-modernizacao-conservadora/30607>. Aces-
} so em: 23 mai. 2018. 
acesso, o protagonista tem que fazer sacrifícios econômicos e afetivos. No entanto, estes mementos não suprem a ausência do migrante. Os objetos, que são exemplos da lógica do consumo, outro derivado da modernização conservadora conduzida pela ditadura, são apenas simulacros (BAUDRILLARD, 1981).

O romance de Ruffato aborda a força das relações afetivas, através da utilização da memória e da escrita como fio condutor da manutenção desse afeto, transpondo as barreiras físicas e geográficas da saudade, tentando manter a presença dos laços familiares através das cartas. Em De mim já nem se lembra fica nítido que, por mais que José Célio não esteja presente fisicamente em Cataguases, ele ainda é a figura principal da família. Sua ausência física não apaga sua presença afetiva, mas sim, torna-o ainda mais presente, evidenciando que a saudade não acomete somente os que vão, mas também os que ficam.

Apesar da luta contra o apagamento das relações de afeto e contra a substituição dessas relações pelas de trabalho e consumo, São Paulo representa a fluidez das relações do mundo moderno e o aumento progressivo da complexidade das tarefas laborais, principalmente aquelas relacionadas às indústrias e suas máquinas, e como esta complexidade afeta as relações interpessoais vividas pelo sujeito migrante. Assim, segundo Bauman (2000), a modernidade líquida com toda sua aceleração industrial, que refletiu e alterou as relações sociais e de trabalho, faz-se pertinente ao ensaio. Bauman (2000) afirma que:

O espaço público é feito para servir aos consumidores, ou, ainda, transubstanciar o residente (da cidade) em um consumidor [...] tais espaços encorajam ação e não interação. [...] a tarefa é o consumo, e consumo é intrinsecamente e irremediavelmente um entretenimento individual, um fio condutor de sensações que podem ser experienciadas somente subjetivamente, através da vivência (p. 97).

Estabelecendo um diálogo entre Bauman e Augé, este afirma que espaços públicos de convivência são atrelados a uma relação de consumo somente, e não buscam uma relação interpessoal, e sim, uma experiência mais isolada e individual ao navegar pela cidade. Em Bauman, o espaço de convivência é restrito às relações de negociação, e o objetivo final acaba sendo as relações de consumo, as quais alteraram e reformularam as relações pessoais. Enquanto de Certeau defende a construção do espaço pelas práticas cotidianas do sujeito e Augé estabelece diferentes acepções para lugar, o presente artigo limita-se a sua concepção de lugar como espaço de reconhecimento e construção de um eu-social. Neste sentido, a justaposição entre o espaço de Cataguases e o não espaço de São Paulo destaca a trajetória de perdas gerada pela modernidade líquida/conservadora. Em outras palavras, De mim já nem se lembra estabelece uma dicotomia implícita que abarca não somente o espaço geográfico Cataguases/São Paulo, mas também uma espacialidade afetiva que é fraturada pelo projeto modernizador da ditadura. 
O clímax da narrativa é também o ápice da relação de José Célio e o consumo. Apesar da anulação afetiva e social, ele continua a ajudar financeiramente sua família com o dinheiro que recebe e ainda consegue consumir: compra um carro usado. Ele decide inaugurar a aquisição do bem com uma viagem a Cataguases, para mostrar à família que todo o sacrifício e esforço estava sendo recompensado. Termina morto por um dos símbolos mais potentes do projeto de industrialização da ditadura: um fusca. É no carro (comprado de segunda mão) que José Célio morre ao sofrer um acidente na viagem de retorno à casa, ao lugar da afetividade, da memória. $O$ acidente pode ser lido como uma metáfora do atropelamento destes espaços mnemónicos e afetivos pela modernização impiedosa imposta pelo regime militar.

\section{CONSIDERAÇÕES FINAIS}

Através da cartografia do sujeito social em De mim já nem se lembra, pode-se concluir que o processo de modernização e desenvolvimento econômico do Brasil na década de 70 deve muito aos migrantes que saíram de suas comunidades no interior do Brasil, deixando para trás seus laços afetivos e sociais, famílias, amigos, narrativas não escritas e histórias não vividas. Levaram na mala poucos pertences pessoais, mas muito de suas memórias individuais e coletivas, momentos de afeto compartilhados com familiares e amigos, lembranças da vida que tiveram e a esperança de um futuro promissor para quem deslocava-se e para quem ficava.

A ditadura militar, apesar de não ser o foco principal desse ensaio, exerce um papel fundamental para compreender o reposicionamento do sujeito migrante na obra de Ruffato. 0 regime de exceção existiu pela ausência, e não pela presença: ausência de direitos humanos, liberdade, direito de expressão, afeto. De mim já nem se lembra acrescenta mais uma ausência a este catálogo: a presença da ausência dos migrantes que fizeram possivel a modernização conservadora da ditadura e que deixarem para trás uma paisagem de perdas, de silêncios, de histórias não contadas.

Dessa forma, a migração de membros das classes populares de zonas rurais para as grandes capitais brasileiras em busca de uma vida melhor configura uma utopia ${ }^{14}$, alimentada pela oferta de emprego e ilusória possibilidade de ascensão social, sacrificando as relações dentro do cosmo social familiar. Essa tentativa de reposicionamento de lugar, fruto da busca por outro, promissor, mas incerto, falha. A literatura, então, surge como ferramenta para construir esse lugar de afeto e de enunciação que carece a sujeitos como José Célio. Restando as cartas como o espaço de agência da vivência, papel social e afetiva do sujeito migrante. A literatura serve, assim, como estratégia de resistência ao apagamento das

14 Utopia aqui é empregado como construções imaginárias de sociedades perfeitas, sendo, portanto, um não lugar, vazio de significado. 
práticas afetivas e ao esgarçamento das relações familiares e sociais. Contrapõe-se ao não espaço, à modernidade líquida que erode as relações sociais.

As cartas de José Célio materializam a saudade do núcleo familiar, além de servir de base para a construção de um espaço de pertencimento social, numa luta inconsciente de resistência ao apagamento das relações de afeto.

Portanto, pode-se afirmar que a literatura é um espaço que pode constituir um lugar de expressão de discursos silenciados pela ideologia imposta pelo Estado de exceção. A literatura pode concretizar essas narrativas silenciadas ou silenciosas, afirmando a necessidade de ouvir as vozes que foram apagadas ou esquecidas e escrever outras histórias com outras verdades. Segundo Luiz Ruffato:

Não acho que escritores tenham obrigação de se engajar em política. Refletir sobre a realidade imediata é papel do jornalismo. A literatura está sempre um pouco "atrasada" em relação à História. Mas a importância dela pode estar justamente nisso. 0 que a literatura pode fazer é lançar um olhar ao passado para iluminar o presente. ${ }^{15}$

\section{REFERÊNCIAS}

AUGÉ, Marc. Non-places: Introduction to an Anthropology of Supermodernity. London: Verso, 2006.

BAUDRILLARD, J. Simulacra and simulation. Ann Arbor: University of Michigan Press, 1994.

BAUMAN, Zygmunt. Liquid Modernity. Cambridge, UK: Polity Press, 2015.

CARTAMAIOR. 0 golpe de 64 e a modernização conservadora. Disponivel em: <https://www.cartamaior. com.br/?/Coluna/O-golpe-de-64-e-a-modernizacao-conservadora/30607>. Acesso em: 01 set. 2017.

CERTEAU, Michel de. The Practice of Everyday Life: [1]. Berkeley: U. of California P., 1984.

DURKHEIM, É. Le suicide. 1897.

15 Disponível em: <https://oglobo.globo.com/cultura/livros/cada-romance-uma-tentativa-de-reconstruir-historia-diz-ruffato-18960961>. Acesso em: 27 set 2017. 


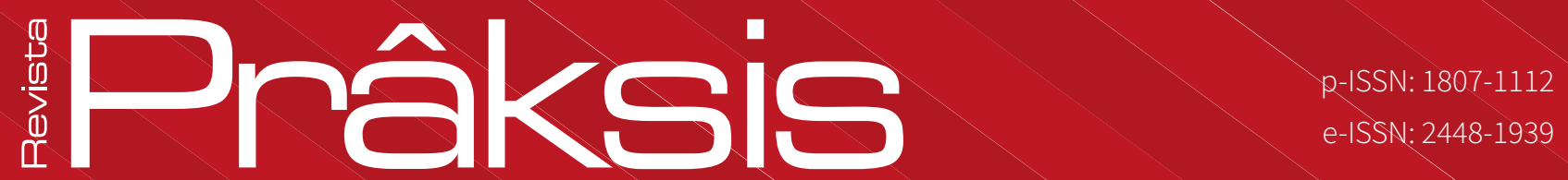

O GLOBO. Cada romance uma tentativa de reconstruir historia diz Ruffato. Disponível em: <https:// oglobo.globo.com/cultura/livros/cada-romance-uma-tentativa-de-reconstruir-historia-dizruffato-1896096>. Acesso em: 01 set. 2017.

RUFFATO, Luiz. De mim já nem se lembra. São Paulo: Companhia das Letras, 2016.

VELOSO, Fernando A.; VILLELA, André; GIAMBIAGI, Fabio. Determinantes do "milagre" econômico brasileiro (1968-1973): uma análise empírica. Revista Brasileira de Economia, v. 62, n. 2, p. 221-246, 2008. 